\title{
Soil Quality Indexes Response to Land Use Change in Puerto Ayacucho, Venezuelan Amazonia
}

\author{
Danilo López-Hernández ${ }^{1 *}$ \\ ${ }^{1}$ Universidad Central de Venezuela, Instituto de Zoología y Ecología Tropical, Laboratorio \\ de Agroecología, Apdo. 47058, Caracas 1041A, Venezuela. \\ Email: danilo.lopez@ciens.ucv.ve
}

\begin{abstract}
Shifting cultivation (SF) or "conuco" is a form of crop cultivation of native Amerindian in Venezuelan Amazonia. SF is practiced in the primary forest as traditional conuco (TC) or in forestfallow as conuco in fallow (CF). Soil samples were random collected from previously settled conucos (TC and SF) and controls, and compared for fertility parameters (pH, C, N, available-P, Nmineralization), microbial biomass $(\mathrm{C}, \mathrm{N})$ and enzymatic activities. In $\mathrm{CF}$, soil organic matter was drastically reduced (58\%), whereas in the TC there was no significant difference with the control. Soil microbial biomass did not present a consistent trend within TCs, however, a drastic decrease was presented in the CF (59\%). Phosphatase and urease were higher in the traditional conuco than in the primary forest, however the activities of both enzymes drastically declined in the conuco in fallow. Soil enzyme activity and microbial biomass were strongly affected by land degradation and represent very sensitive indicators of soil disturbance.
\end{abstract}

Keywords: Conuco, microbial biomass, phosphatase activity, deforestation, swidden cultivation.

\section{Introduction}

Increasing deforestation for establishment of crop and pastures in Amazonia has become an issue of global concern due to its impacts on biodiversity, climate, and local and regional hydrological cycles $[2,3,4,29]$. However, in Venezuelan Amazonia, deforestation of the tropical rain forests surrounding Puerto Ayacucho, the capital of Amazonas State, is caused for both the establishment of cattle ranches by creoles (criollos), and the demographic growth and resettlement of native communities and internal migrations from other Venezuelan regions [23].

Traditionally, natives as well as creoles have practiced in the rain forest an agriculture system (AS) locally called conuco (the local name for slash and burn or swidden cultivation), an itinerant ecologically-sustainable agriculture system based on slash-and-burn of primary and secondary forests $[18,19,32,35]$. However, the lack of enough primary forestland for the growing population has rendered the traditional conuco (TC) unsustainable. In turn, the utilization of young secondary forest (fallow) land, in many cases drastically shortened to less than 7 years of fallowing as a conuco in fallow $(\mathrm{CF})$, has also contributed to the rate of "savannization" of the rain forest and to a drastic drop of food productivity [26]. With the relocation in the savanna and the acculturation, the traditional itinerant conuco was replaced, among other agricultural systems, by a sedentary "improved conuco" (IC) that has less diversity of crops and uses large amounts of chemical fertilizers. However, agricultural activities in the State, particularly the different types of conucos, are not able to feed the growing population, and food is imported from other Venezuelan regions. Therefore, around Puerto Ayacucho, there co-exist many indigenous/creole communities which use different agricultural systems to produce food-crops.

Land use change alters the below-ground ecosystem, leading to depletion of soil carbon and loss of biodiversity $[3,6,9]$. Research on the effects of land use change has primarily focused on the effects on physical and chemical properties, with less focus on soil biology with the exception of the importance of earthworms and termites in regulating nutrient cycling in forest and savanna soils [20]. Besides, losses in soil carbon by land use change can be considerable, and indigenous microbial communities respond to such changes in carbon and other substrates through modifications in the microbial biomass and enzymatic activities $[7,9,11,15,26]$. In general, soil microbial biomass is higher in ecosystems that receive permanent inputs of organic residues as found in native forest or regenerated lands [15]. Moreover, the 
availability of fresh organic residues under native vegetation and in restored land likely stimulated soil enzymatic activity [15].

Waldrop et al. [42] have shown that conversion of forest to agriculture decreased microbial biomass and produced compositionally distinct microbial communities in Tahiti, similar results have presented by López-Hernández [23] in Venezuelan Amazonia, whereas Borneman and Triplett [6] by molecular microbial have demonstrated significant differences between soil microbial populations in a mature forest and adjacent pasture in Eastern Amazonia. There is a complete lack of information on the impact of shifting cultivation on soil organic carbon in the forests surrounding Puerto Ayacucho, although a very important work was done in the 70s in the forests located in the southern part of Venezuelan Amazonia in San Carlos de Rio Negro, particularly in the structure and functioning of the rain forest with emphasis on processes related to the impact of deforestation and land use change on nutrient cycling [14]. Therefore, less information is known in Venezuelan Amazonian soils about: how agricultural practices affect parameters more recently studied of soil use change like microbial biomasses and enzymatic activities?

The main objectives of this contribution were (i) to determine the variations in soil fertility parameters, microbial biomass and enzymatic activities with control forest soils, slash and burnt sites under different agricultural systems, and, (ii) to determine the above mentioned responses, soil fertility, microbial biomass, enzymatic activities with primary forest soils and courses in fallow under different agricultural systems and ages.

\section{Materials and Methods}

\subsection{Physical and Geographic Characterization}

The agricultural systems (AS) studied were located in the surrounding forests around Puerto Ayacucho $\left(5^{\circ} 3^{\prime} 47^{\prime \prime} \mathrm{N}, 67^{\circ} 37^{\prime} 35^{\prime} \mathrm{W}\right)$, Amazonas State, Venezuela (Figure 1). The average annual temperature of the zone is $28^{\circ} \mathrm{C}$; the mean annual precipitation near Puerto Ayacucho is $2200 \mathrm{~mm}$ although, in the southern part of the state, precipitation can reach $4000 \mathrm{~mm}$ [18,26]. The main parent material of soils in the zone is the granite of Parguaza and the Roraima formation [37]. Because of the high precipitation and temperature, soils in general, are strongly weathered [5,12,27]. Ultisols and oxisols (USDA) [40] are common in the area, although sandy entisols are also found $[5,12,26]$. Because of the high precipitation and temperature, soils in general, are strongly weathered with a low natural fertility and strong phosphorus and nitrogen deficiencies [31].

Most of the vegetation in Amazonas State is primary forest [17,32] and there are several types of forest according to the depth and fertility of soils.

The following agricultural systems were identified in the area surrounding Puerto Ayacucho. All the identified AS and controls were sampled for the determination of soil quality indexes.

\subsection{Agricultural Systems in the Forest}

\subsubsection{Traditional Conuco (TC)}

The TC corresponds to the well-known subsistence native Amerindian swidden cultivation system $[10,18,21]$. This TC is based in the slash-and- burn of a small primary forest area (less of 2 ha) by the use of rudimentary tools as long-bladed knifes (machetes). Multicrops are planted by the Indian family group for their subsistence and the only capital input is the labor force of each member. After a short time (around 3 years), the conuco is abandoned and another one is opened in a new area of the forest no far away from the former conuco $[21,35]$. The great varieties of crops found in the TC resemble the high biodiversity existing in the forest. Despite that the forest is cleared to build up this type of conuco, its size is so small that, within it, the original forest microclimate is preserved. Apart from introduced crops, also many local fruit plants of the Amazonian region are found in TC. 


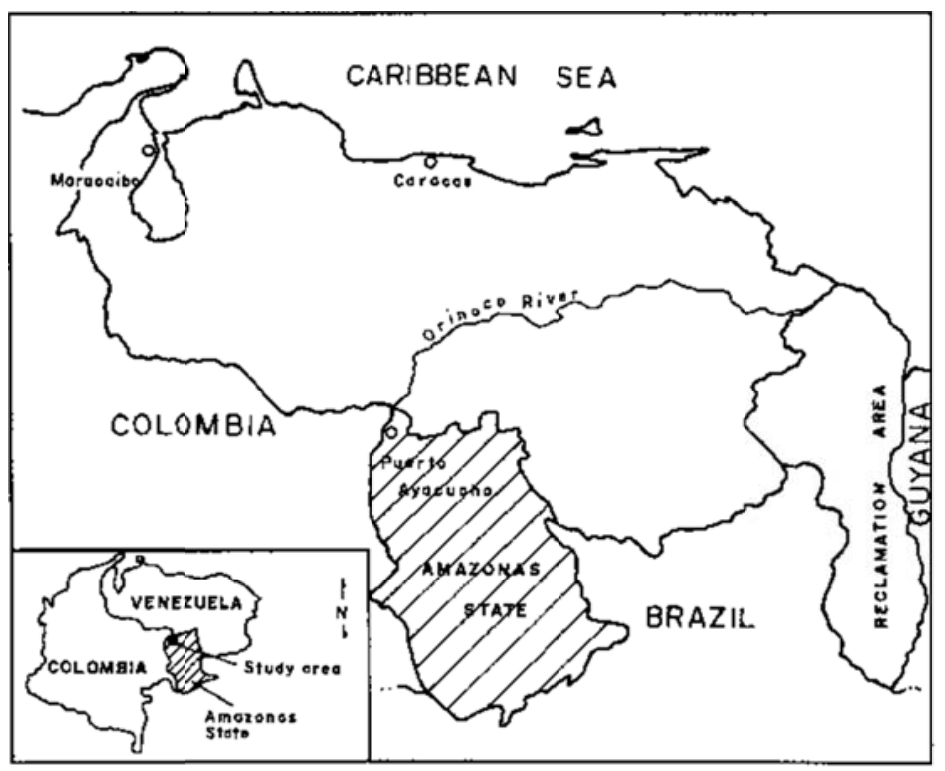

Figure 1. Geographical location of the studied sites in Amazonas State, Venezuela.

\subsubsection{Conuco in Fallow $(\mathrm{CF})$}

Differently from the TC, this conuco, which is used by native, is located in secondary forest (fallow). As a consequence of the scarcity of forest land, many communities had to reuse the secondary forest within short periods of time (less than 10 years). CF uses slash and burn techniques but due to the low amount of nutrients (ashes) produced by a young fallow the soil is very poor in nutrients, therefore there is not much crop diversification in the $\mathrm{CF}$ and the main crops produced are the bitter cassava (Manihot esculenta) and pineapples (Ananas comosus).

Two experimental sites were sampled: Pavoni located $46 \mathrm{~km}$ in the northern part of Puerto Ayacucho (PA) and Rueda-Matamina $16 \mathrm{~km}$ in the southern part of PA.

Pavoni is the Indian community of the Curripaco ethnic group, located in the savanna strip extending between the Orinoco River and the tropical high forest. The community has approximately 127 inhabitants. The northern part of the community is surrounded by Trachypogon savanna with numerous interspersed shrubs and trees. The high forest begins $6 \mathrm{~km}$ east from the locality. The main activities of the inhabitants are agriculture, fishing and hunting; gathering is a minюr activity, and cattle raising is not practiced. The other Amerindian community studied: Rueda-Matamina, is a community of the Guajivo ethnic group, located also in the Trachypogon savanna extending between the Orinoco River and the high tropical forest. The community has approximately 107 inhabitants. The main activities of the inhabitants are agriculture, fishing and hunting, and cattle raising is not practiced.

The agricultural systems were chosen attending the following criteria: the undisturbed tropical high forest or the fallow to start a new traditional conuco or a conuco in fallow, respectively were located in a distance not far from the community, so that the natives can access to the conuco in about less than one hour walking or by bicycle, the sites were slightly elevated to prevent flood and with a near stream to have water for consumption and for washing vegetables before bringing them to the village. The conucos (TC and $\mathrm{CF}$ ) were settled down by the natives before our soil sampling, sor our validation of soil indexes, was done in ex-post-facto experiments.

We included in our analysis two TCs and their respective controls (primary forest), one TC was located in the northern part of Puerto Ayacucho (PA) at the locality of Pavoni, the other in the southern part of PA at Rueda-Matamina. The study of the CFs was performed only at Pavoni, where two CFs of six months and three years old, respectively, and their respective fallow control were sampled. 


\subsection{Soil Sampling and Analysis}

In each experimental site, triplicate soil samples in the AS and in the forest control (primary forest or fallow) were collected. Each triplicate was a composite sample constituted of ten soil subsamples collected at random from 0 to $10 \mathrm{~cm}$ of the soil mineral layer in the treatment site and in the control. After drying and sieved through 2-mm mesh, soil samples were analyzed for soil $\mathrm{pH}$ (measured in a ratio 1:5 soil:water), organic matter content (Walkley and Black method), total nitrogen (Kjeldahl method). $\mathrm{N}$ potentially mineralizable (N0) was measured after one month incubation according to the method of Stanford and Smith [36]. Available phosphorus was extracted with sodium bicarbonate, whereas phosphorus in the extracts was determined by Murphy and Riley [30] method.

\subsection{Sampling for Additional Biochemical and Microbial Biomass Studies}

Additionally to the sampling for soil fertility studies, another sampling was performed to characterize complementary biochemical and microbial biomass parameters. Triplicate soil samples in the AS and in the control soil were collected at random from 0-10 $\mathrm{cm}$ depth and sieved through 2-mm mesh. Samples were kept refrigerated until further analysis.

\subsubsection{Microbial $\mathrm{C}$ and $\mathrm{N}$ Biomass}

Triplicate $15 \mathrm{~g}$ of intact soil, were used to determine $\mathrm{N}$ microbial biomass (N-MB) and $\mathrm{C}$ microbial biomass (C-MB). C-MB and N-MB were determined by the fumigation-extraction method using freealcohol chloroform $[8,41]$. N-MB was calculated as the difference in total $\mathrm{N}$ extracted in the fumigated and non-fumigated soil [8]. The $\mathrm{C}-\mathrm{MB}$ was calculated as the difference between $\mathrm{C}$ extracted in fumigated and non-fumigated soils [41]. Microbial P (P-MB) was also determined by the chloroform fumigation-extraction method according to Hedley et al. [13]. The P-MB was calculated as the difference between $\mathrm{P}$ extracted in fumigated and non-fumigated soils.

\subsubsection{Enzymatic Activities}

Acid phosphatase activity (APA) was determined colorimetrically as the degradation of PNP-P (pnitrophenyl phosphate) to PNP after a 30 min incubation of $1 \mathrm{~g}$ fresh soil sample at $\mathrm{pH} 6.5$ [38], while urease activity (UA) was determined according with the method of Tabatabai and Bremner [39]. For microbial and enzymatic activities, values were corrected for humidity contents.

\subsection{Statistical Analysis}

The results of soil quality indicators were analyzed statistically from triplicate data grouped from the Agricultural System and triplicate data from the control. Data were subjected to a one-way ANOVA STATGRAPH Program. The nonparametric Wilcoxon-Mann-Whitney test was performed to compare means using the software package Statistic 5.1 for Windows. Statistical significance was assumed when $\mathrm{p}<0.05$.

\section{$3 \quad$ Results}

\subsection{Changes in the Fertility of Soils in Relation to Land Use}

Data of experiments done ex-post-facto in the $\mathrm{TC}$ and $\mathrm{CF}$ of the indigenous communities of Pavoni (Table 1) show that soil $\mathrm{pH}$ increases as compared with the control because of the neutralizing effect of the soluble bases supplied by ash on soil acidity. Additionally, available $\mathrm{P}$ in the TC also presents a small increase after burning since the relatively low amounts of soluble $\mathrm{P}$ coming from the ashes are rapidly incorporated (retained) by the mineral matrix of the soil. The conuco in fallow did not differ in the content of available $\mathrm{P}$ respect the soil control (Table 1).

In the conuco located at Pavoni there was no significant difference in total $\mathrm{C}$ between the $\mathrm{TC}$ and the primary forest, whereas at Rueda-Matamina total carbon increased significantly in the traditional conuco (TC) respect the control, perhaps due to the presence of organic debris that still were remaining in the soil once the original forest was cut off. In the $\mathrm{CF}$ of Pavoni the organic matter content also did not differ with the fallow control. 
Total nitrogen in the different forest production systems, in general was low, as expected for conucos located in tropical forest, and for both $\mathrm{TC}$ and $\mathrm{CF}$, values did not differ significantly from the control. $\mathrm{C} / \mathrm{N}$ ratios in TC and CF were similar (28-34), except for a significant higher value at Rueda-Matamina (45) due to the important amount of $\mathrm{C}$ presented in this conuco (Table 1). In general, the rate of nitrogen mineralization for the different type of conucos ( $\mathrm{TC}$ and $\mathrm{CF}$ ) did not present a consistent trend with respect to their respective controls, although the information was not very variable (16-27 $\mu \mathrm{g} g-1)$.

Table 1. Comparison of soil quality indexes of controls and two traditional conucos (TC) and one conuco in fallow (CF) located near Puerto Ayacucho, Amazonas State, Venezuela

\begin{tabular}{|c|c|c|c|c|c|c|}
\hline Locality & $\begin{array}{l}\mathrm{TC} \\
\text { Pavoni }\end{array}$ & $\begin{array}{l}\text { Primary Forest } \\
\text { Control Pavoni }\end{array}$ & $\begin{array}{l}\text { TC } \\
\text { Rueda-Matamina }\end{array}$ & $\begin{array}{l}\text { Primary Forest } \\
\text { Control } \\
\text { Rueda-Matamina }\end{array}$ & $\begin{array}{l}\mathrm{CF} \\
\text { Pavoni }\end{array}$ & $\begin{array}{l}\text { Fallow } \\
\text { Control Pavoni }\end{array}$ \\
\hline $\mathrm{pH}$ & $6.0 \mathrm{a}$ & $5.4 \mathrm{~b}$ & $5.2 \mathrm{a}$ & $4.5 \mathrm{~b}$ & $5.7 \mathrm{a}$ & $4.6 \mathrm{~b}$ \\
\hline$\% \mathrm{C}$ & $2.3 \mathrm{a}$ & $1.9 \mathrm{a}$ & $3.4 \mathrm{a}$ & $2.0 \mathrm{~b}$ & $1.3 \mathrm{a}$ & $1.3 \mathrm{a}$ \\
\hline $\mathrm{N}(\mu \mathrm{g} g-1)$ & $690 \mathrm{a}$ & $560 \mathrm{a}$ & $744 \mathrm{a}$ & $677 \mathrm{a}$ & $387 \mathrm{a}$ & $481 \mathrm{a}$ \\
\hline $\mathrm{C} / \mathrm{N}$ & $33 \mathrm{a}$ & $34 \mathrm{a}$ & $45 \mathrm{a}$ & $30 \mathrm{~b}$ & $33 \mathrm{a}$ & $28 \mathrm{a}$ \\
\hline Avail P ( $\mu g$ g-1) & $1.5 \mathrm{a}$ & $0.6 \mathrm{a}$ & $2.0 \mathrm{a}$ & $0.4 \mathrm{~b}$ & $1.4 \mathrm{a}$ & $2.2 \mathrm{a}$ \\
\hline $\mathrm{N} \min (\mu \mathrm{g} g-1)$ & $22 \mathrm{~b}$ & $27 \mathrm{a}$ & $24 \mathrm{a}$ & $18 \mathrm{~b}$ & $21 \mathrm{a}$ & $16 \mathrm{~b}$ \\
\hline C-BM ( $\mu \mathrm{g} g-1)$ & $220 \mathrm{a}$ & $218 \mathrm{a}$ & $37 \mathrm{~b}$ & $98 \mathrm{a}$ & $141 \mathrm{a}$ & $154 \mathrm{a}$ \\
\hline $\mathrm{N}-\mathrm{BM}(\mu \mathrm{g} g-1)$ & $34 \mathrm{a}$ & $15 \mathrm{~b}$ & $19 \mathrm{a}$ & $17 \mathrm{a}$ & $18 \mathrm{a}$ & $10 \mathrm{~b}$ \\
\hline P-BM ( $\mu g$ g- 1$)$ & 0.5 & 0.5 & -1.1 & -1.4 & -2.5 & -0.7 \\
\hline PA ( $\mu g$ g-1h-1) & $29 \mathrm{a}$ & $21 \mathrm{~b}$ & $16 \mathrm{a}$ & $8 \mathrm{~b}$ & $18 \mathrm{a}$ & $4 \mathrm{~b}$ \\
\hline $\mathrm{UA}(\mu \mathrm{g} g-1 \mathrm{~h}-1)$ & $50 \mathrm{a}$ & $39 \mathrm{~b}$ & $29 \mathrm{a}$ & $13 \mathrm{~b}$ & $22 \mathrm{a}$ & $22 \mathrm{a}$ \\
\hline
\end{tabular}

Means followed by different letters differ statistically $(\mathrm{p}<0.05)$. Avail $\mathrm{P}=$ Available $\mathrm{P} ; \mathrm{N}$ min $=\mathrm{N}$ mineralizable

\subsection{Changes in Microbial and Enzymatic Activities of Soils in Relation to Land Use}

A consistent trend in the carbon microbial biomasses of the different conucos with respect to control soils was not found. The highest value in microbial C-biomass (C-MB) was shown in the traditional conuco located at Pavoni (Table 1$)$, however significance $(\mathrm{p}<0.05)$ was not found between the conuco and the control forest site, on the contrary the C-MB value in the TC of Rueda-Matamina was lower than in Pavoni with a significant decline in the agricultural system with respect to control. Agricultural activities in the fallow site of Pavoni did not affect carbon microbial biomass.

Also a consistent trend in the nitrogen microbial biomasses of the different conucos with respect to control soils was not found. Nitrogen microbial biomass was the double in the TC of Pavoni (34 $\mu \mathrm{g} g-1)$ in comparison with the control $(15 \mu \mathrm{g} g-1)$, whereas at Rueda-Matamina significance was no found between the agricultural system and the control (Table 1), in the case of the CF, there was a significant $(\mathrm{p}<0.05)$ decline in $\mathrm{N}-\mathrm{BM}$ in the control respect the $\mathrm{CF}$.

All the microbial Pi values were very low $(<1 \mu \mathrm{g} g-1)$, moreover many of the results were negatives because of the high phosphorus adsorption capacities of the soil of the zone [23]. Phosphatase activity (PA) in the conucos ( TC and $\mathrm{CF}$ ) increased in all the cases respect the soil controls, while urease activity (UA) significantly increased in the TCs when compared with the soil of the primary forest (control); however it was not affected by agricultural activities in the fallow site.

\subsection{Variation in Soil Quality Indexes between the Original Primary Forest and the Different Agricultural Soils}

At Pavoni site, under the original primary forest, traditional conucos and conucos in fallow have been established. A comparison of the soils of the 3 sites for different indicators of soil quality presented the following results (Table 2). The original acidic soil $\mathrm{pH}$ of the primary forest increased in TC as result 
from the ashes coming from the burning operations, but then it declined significantly in the soil under fallow. Total carbon and nitrogen did not differ between primary forest and TC; however both parameters drastically significantly $(\mathrm{p}<0.05)$ declined in the fallow site respect the control $(58$ and $68 \%$, respectively). Available $\mathrm{P}$ is low in all the soils with a tendency to increase in the agricultural systems, in contrary, N-mineralization decreases significantly in the agricultural sites when compared with the original primary forest ( 82 and $67 \%$ for TC and CF, respectively, Table 2).

In that which concerns microbial and enzymatic activities, carbon microbial biomass presented a significant decreased in the fallow system when compared with the other two sites, whereas in the case of nitrogen microbial biomass the conuco in fallow declined respect the traditional conuco, however it presented a value almost similar to the primary forest. For the enzymatic activities, both phosphatase and urease increased significantly in TC respect the primary forest site; however values significantly decreased in the fallow system.

\subsection{Changes in Soil Quality Parameters in Relation to the Age of Land Use}

A comparison of two conucos in fallow, one of three months of age and the other of three years old, indicated that some of the soil quality parameters varied according to the time of land use (Table 3). For $\mathrm{pH}, \mathrm{N}$ mineralizable and phosphatase activity the values decreased significantly $(\mathrm{p}<0.05)$ during the three years of crop use, whereas in the case of total organic, total nitrogen, $\mathrm{C}$ and $\mathrm{N}$ biomasses and urease activity although there was a slight decrease on time, statistical significance was no reached, on the contrary available $\mathrm{P}$ had a small significant increase after three years of cropping.

Table 2. Comparison of the soil quality indexes of the primary forest (control) with the traditional conuco (TC) and conuco in fallow (CF) located at Pavoni, near Puerto Ayacucho, Amazonas State, Venezuela.

\begin{tabular}{|c|c|c|c|}
\hline Locality & $\begin{array}{l}\text { Primary Forest } \\
\text { Control }\end{array}$ & $\begin{array}{l}\text { TC } \\
\text { Pavoni }\end{array}$ & $\begin{array}{l}\mathrm{CF} \\
\text { Pavoni }\end{array}$ \\
\hline $\mathrm{pH}$ & $5.4 \mathrm{~b}$ & $6.0 \mathrm{a}$ & $4.9 \mathrm{~b}$ \\
\hline$\% \mathrm{C}$ & $1.9 \mathrm{a}$ & $2.3 \mathrm{a}(121)$ & $1.1 \mathrm{~b} \mathrm{(58)}$ \\
\hline $\mathrm{N}(\mu \mathrm{g} g-1)$ & $560 \mathrm{a}$ & 690 a (123) & $380 \mathrm{~b}(68)$ \\
\hline $\mathrm{C} / \mathrm{N}$ & $34 \mathrm{a}$ & $33 \mathrm{a}$ & $30 \mathrm{a}$ \\
\hline Avail. P ( $\mu \mathrm{g} g-1)$ & $0.6 \mathrm{a}$ & $1.5 \mathrm{a}$ & $3.7 \mathrm{a}$ \\
\hline $\mathrm{N}$ miner. $(\mu \mathrm{g} g-1)$ & $27 \mathrm{a}$ & $22 \mathrm{~b}(82)$ & 18 c (67) \\
\hline C-BM ( $\mu g \mathrm{~g}-1)$ & $218 \mathrm{a}$ & 220 a $(101)$ & $129 \mathrm{~b}(59)$ \\
\hline N-BM ( $\mu g$ g-1) & $15 \mathrm{~b}$ & 34 a (227) & $16 \mathrm{~b}(107)$ \\
\hline P-BM ( $\mu g$ g-1) & 0.5 & 0.5 & -0.3 \\
\hline PA ( $\mu g g-1 h-1)$ & $21 \mathrm{a}$ & $29 \mathrm{~b}(138)$ & 4 c (19) \\
\hline $\mathrm{UA}(\mu \mathrm{g} g-1 \mathrm{~h}-1)$ & $39 \mathrm{~b}$ & 50 a (128) & 15 c (39) \\
\hline
\end{tabular}

Values in brackets correspond to \% respect control (primary forest). Means followed by different letters differ statistically $(\mathrm{p}<0.05)$. Avail $\mathrm{P}=$ Available $\mathrm{P} ; \mathrm{N}$ min $=\mathrm{N}$ mineralizable

\section{Discussion}

Forests provide a range of ecosystem functions that are fundamental to sustaining terrestrial systems, and also contribute vital support to the provisioning of ecosystem goods and services needed to maintain human populations $[1,4,33]$. However after forest clearance those beneficial traits are reduced, therefore subsequent policy instruments, such as payments for ecosystem services have been developed to financially compensate land managers for preserving ecosystem services and refraining from destructive land-use practices $[33,43]$. 
Table 3. Comparison of the soil quality indexes of conuco in fallow (CF) of different ages located at Pavoni, near Puerto Ayacucho, Amazonas State, Venezuela.

\begin{tabular}{|c|c|c|}
\hline Soil Parameter & $\begin{array}{l}\mathrm{CF} \\
\text { Pavoni recent }\end{array}$ & $\begin{array}{l}\mathrm{CF} \\
\text { Pavoni } 3 \text { years }\end{array}$ \\
\hline $\mathrm{pH}$ & $5.7 \mathrm{a}$ & $4.9 \mathrm{~b}$ \\
\hline$\% \mathrm{C}$ & $1.3 \mathrm{a}$ & $1.1 \mathrm{a}$ \\
\hline $\mathrm{N}(\mu \mathrm{g} g-1)$ & $387 \mathrm{a}$ & $380 \mathrm{a}$ \\
\hline $\mathrm{C} / \mathrm{N}$ & $33 \mathrm{a}$ & $30 \mathrm{a}$ \\
\hline Avail. P ( $\mu \mathrm{g} g-1)$ & $1.4 \mathrm{~b}$ & $3.7 \mathrm{a}$ \\
\hline $\mathrm{N}$ miner. ( $\mu \mathrm{g} g-1)$ & $21 \mathrm{a}$ & $18 \mathrm{~b}$ \\
\hline C-BM ( $\mu g \mathrm{~g}-1)$ & $141 \mathrm{a}$ & $129 \mathrm{a}$ \\
\hline N-BM ( $\mu \mathrm{g} g-1)$ & $18 \mathrm{a}$ & $16 \mathrm{a}$ \\
\hline P-BM ( $\mu \mathrm{g} g-1)$ & -2.5 & -0.3 \\
\hline PA ( $\mu g$ g-1h-1) & $18 \mathrm{a}$ & $4 \mathrm{~b}$ \\
\hline UA ( $\mu g g-1 h-1)$ & $22 \mathrm{a}$ & $15 \mathrm{a}$ \\
\hline
\end{tabular}

Means followed by different letters differ statistically $(\mathrm{p}<0.05)$. Avail $\mathrm{P}=$ Available $\mathrm{P} ; \mathrm{N}$ min $=\mathrm{N}$ mineralizable

\subsection{Changes in the Fertility of Soils in Relation to Land Use}

In the traditional conuco as well as in the conuco in fallow, fertilization comes entirely from the ashes of the slashed and burnt trees. Consequently, soil fertility before crop planting is increased by the amount of ashes produced, which, in turn, depended on the forest age. Therefore, the amount of ashes after burning in a fallow system scarcely provides crop maintenance. Burning releases needed plant nutrients into the soil (phosphorus and cations) producing a quick raise in soil $\mathrm{pH}$ of the acidic soils of Amazonia $[10,21]$. That initial increment in $\mathrm{pH}$ gradually decreases due to leaching and plants and microorganisms uptake of bases as long as the agricultural systems age, which is the case of the two different aged conucos in fallow, located at Pavoni, where a lower fertility was measured in the case of the older conuco (Table 3). The neutralization of the $\mathrm{pH}$ also operates reducing $\mathrm{P}$-adsorption and consequently increasing available-P [24,34]. Available-P in the TC (Table 1) presents a small increase after burning that was significant in the case of the conuco located at Rueda-Matamina. However, the relatively low amounts of soluble $\mathrm{P}$ coming from the ashes are rapidly incorporated (retained) by the mineral matrix (hydrous $\mathrm{Fe}$ and $\mathrm{Al}$ forms) of the soil $[22,23]$. Moreover, the bare surface of the soil after clearance (case of the conuco in fallow recent established), could contribute to increase $\mathrm{P}$ adsorption due to a reduction of organic matter decomposition, since it is a well-known fact that organic matter can block adsorption sites [21,23]. Since phosphorus is a common limiting element in Amazonia's rain forest, it must be emphasized that the small available $\mathrm{P}$ increments registered in the case of the TC are well below the limit necessary for local crops, what may contribute to explain the relative short useful life of a tropical forest conuco $[10,12,21]$. In fact, one of the main reasons to abandon the conuco is the reduction in time of the levels of available phosphorus and exchangeable bases $[18,21,34]$.

Land-use changes, especially the conversion of native forest vegetation to cropland and plantations in tropical region, can alter soil $\mathrm{C}$ and $\mathrm{N}$ pools and $\mathrm{N}$ availability for plant uptake. Soil is a main compartment involved in the biogeochemical cycles of carbon $(\mathrm{C})$ and nitrogen $(\mathrm{N})$, and thus is a key compartment for climate regulation either by emitting greenhouse gases (GHGs) or by sequestering $\mathrm{C}$ $[4,25]$. Thus, the first meters of mineral soils of the world store vast amounts of organic $\mathrm{C}$, which is about three to four times the amount of $\mathrm{C}$ in world vegetation and twice to three times the amount in the atmosphere [4].

The conversion of forest into cropland generally leads to reduction of organic carbon content. However research quantifying changes in soil contents of $\mathrm{C}$ following forest-to-pasture conversion in Amazonia and other tropical regions has rendered conflicting results, ranging from net gains in $\mathrm{C}$ contents to net losses, also some studies found no change [28]. 
At Pavoni after deforestation and conversion of the primary forest in a conuco in fallow, soil organic matter was drastically reduced $(58 \%)$, whereas in the case of the traditional conuco there was no significant difference with the original soil (Table 2), on the contrary at Rueda-Matamina (Table 1) total carbon increased significantly in the traditional conuco (TC) respect the control, showing the inconsistency already mentioned [28].

Immediately following the slash-and-burn conversion of forest to annual crops or pastures, rates of $\mathrm{N}$ mineralization and nitrification may increase in tropical forest soils [16], often followed by a rise in mineral $\mathrm{N}$, which, if not taken up by crop plants, is vulnerable to loss by leaching [25]. Although here no statistical differences were found in concentrations of total soil-N between primary forest and the traditional conuco, there was however a significant decline when compared with the conuco in fallow (68\%), also the rate of N-mineralizable presented significant statistical differences between the primary forest and the agricultural systems, which were more accentuated in the case of the CF.

\subsection{Changes in Microbial and Enzymatic Activities of Soils in Relation to Land Use}

Many studies have documented soil microbial responses to forest disturbances, but the results among these studies are inconsistent. While some studies find increases in microbial abundance following disturbances, others report negative microbial responses to disturbance; therefore we lack a quantitative synthesis across disturbance types [15]. In a comprehensive meta-analysis work, Holden and Treseder [15] have reported that soil microbial biomass significantly decreased following disturbances, by an average of $29.4 \%$, emphasizing that forest fires cause soil disruption in the form of soil combustion and heating of the soil surface. Soil surface temperatures during forest fires can reach up to $600^{\circ} \mathrm{C}$, which is well above the upper thermal limit of most microbial taxa. In addition, soil temperatures often increase following slash and burn operations, and this may augment microbial respiration and thus can result in long-term declines in soil C. Soil microbial biomass was not affected in the traditional conuco with respect the primary forest in the conuco located at Pavoni, but a significant decline occurred in the conuco at Rueda-Matamina (Table 1), results that evidence the inconsistency already mentioned in the literature [15]. However, a drastic decrease in carbon microbial biomass was presented in the conuco in fallow located at Pavoni (59\%, Table 2) that no doubt is related to the decline in total carbon and nitrogen in this nutrient-limited agricultural system.

Phosphatase and urease were higher in the traditional conuco than in the primary forest (Tables 1 and 2), however the activities of both enzymes drastically declined in the conuco in fallow (Table 2).

The results show that the soils under the primary forest with an adequate vegetation cover and organic matter content had higher levels of enzymatic activities than degraded soils under fallow suggesting that soil enzyme activities and microbial biomass are strongly affected by land degradation and represent very sensitive indicators of soil disturbance $[15,23]$.

\section{Conclusions}

After deforestation and conversion of the primary forest in a conuco in fallow, soil organic matter was drastically reduced, whereas in the case of the traditional conuco there was not a consistent trend. The results obtained show that the soils under the primary forest had higher levels of enzymatic activities than degraded soils under fallow suggesting that soil enzyme activities and microbial biomass are strongly affected by land degradation and represent very sensitive indicators of soil disturbance. Therefore, the traditional conuco (TC) could be considered economically and ecologically sustainable under three conditions, which, unfortunately, are rarely met within the indigenous communities of the Amazonas State: the existence of enough forest land to recycle yields for periods at least longer than twenty years, that the population does not grow, and that indigenous communities do not get acculturated and do not enter into a market economy. On the contrary, forest land for conucos is getting scarce, and furthermore as the indigenous communities approach urban centers such as Puerto Ayacucho, they get acculturated and incorporate new consumption habits whose satisfaction requires of a surplus-market economy. The conuco in fallow $(\mathrm{CF})$, is not recommended as agricultural system, since is no self-sufficient and is the less productive and environmental destructive of the agricultural systems analyzed. Due to the low amounts of ashes incorporated after burn, crop diversity is restricted. Time for 
recuperation is insufficient increasing the risk of erosion. All the above factors make the CF ecologically unsustainable. In conclusion, agro-ecological policies recommended in Venezuelan Amazonia must be generated within an approach of sustainable agriculture which considers the health of the soil fertility and biodiversity, as well as protecting the natural and human (cultural) resources.

Acknowledgements. I acknowledge Mr. F. Tovar and Dr. Carmen Hernández for field and laboratory technical assistance, respectively. This contribution received financial support from CONICIT Proyecto RP VII 290089

\section{References}

1. R.I. Barbosa, C. Volkmer de C.,R. de O. Perdiz, G. Damasco, R. Rodrigues, P. M. Fearnside, "Decomposition rates of coarse woody debris in undisturbed Amazonian seasonally flooded an unflooded forests in the Rio NegroRio Branco Basin in Roraima, Brazil" Forest Ecology and Management, vol. 397, 1-9, 2017.

2. P.E. Barni, A.O. Manzi, T. M. Condé, R.I. Barbosa and P.M. Fearnside, "Spatial distribution of forest biomass in Brazil's state of Roraima northern Amazonia", Forest Ecology and Management, vol 377, 170-181, 2016.

3. H.S. Barros, P.M. Fearnside, "Soil carbon stock changes due to edge effects in central Amazon forest fragments", Forest Ecology and Management, vol. 379, 30-36, 2016.

4. A. Bispo, L. Andersen, D. A. Angers, M. Bernoux, M. Brossard et al., "Accounting for Carbon Stocks in Soils and Measuring GHGs Emission Fluxes from Soils: Do We Have the Necessary Standards?" Frontiers in Environmental Science, Vol 5 | Article 41, 1-12, 2017 doi: 10.3389/fenvs.2017.00041.

5. P. Blancaneaux, S. Hernández, S. and J. Araujo, Estudio Edafológico Preliminar. Sector Puerto Ayacucho, T. F. A. MARNR. Caracas. 1977.

6. J. Borneman and E.W. Triplett, "Molecular microbial diversity in soils from Eastern Amazonia: evidence for unusual microorganisms and microbial population shifts associated with deforestation", Appl. Environ. Microbiol., vol. 63, 2647-2653, 1997.

7. D.A. Bossio, M.S. Girvan, L. Verchot, J. Bullimore, T. Borelli, A. Albrecht, K.M. Scow, A.S. Ball, J.N. Pretty and A.M. Osborn,"Soil Microbial Community Response to Land Use Change in an Agricultural Landscape of Western Kenya", Microbial Ecology, vol. 49, 50-62, 2005.

8. P. C. Brookes, A. Landman, G. Pruden and P. D. Jenkinson, "Chloroform fumigation and the release of soil nitrogen: a rapid direct extraction method to measure microbial biomass nitrogen in soil", Soil Biol. Biochem., vol 17, 837-842, 1985.

9. C.A. Etok, I.S. Onwuchekwa, N.U. Asamudo and V.C.Nwaugo, "Effect of "slash and burn" operation on agricultural soil quality in Egbema, Southern Nigeria", Nigerian Journal of Microbiology, vol. 25, 2353 - 2362 , 2011.

10.P.M. Fearnside, Agriculture in Amazonia. pp. 393-418 In: G.T. Prance and T.E. Lovejoy (eds.) Key Environments: Amazonia. Pergamon Press, Oxford, U.K. 1985, pp. 442.

11.A.S. Ferreira Araújo, S. Cesarz, L.F. Carvalho Leite, C.D. Borges, S.M. Tsai and N. Eisenhauer, "Soil microbial properties and temporal stability in degraded and restored lands of Northeast Brazil", Soil Biol. Biochem., vol 66, $175-18,2013$

12.P. García, Los Suelos del Estado Amazonas: sus Potencialidades Agrícolas. Venesuelos, 22, 59-66, 1994.

13.M. J., Hedley, J.W. Stewart and B.S. Chauhan, "Changes in inorganic and organic soil phosphorus fractions induced by cultivation practices and by laboratory incubations", Soil Sci. Soc. Am. J, vol 46, 970-976, 1982.

14.R. Herrera, C.F. Jordan, H. Klinge and E. Medina, "Amazon ecosystems. Their structure and function with particular emphasis on nutrients", Interciencia, vol. 3, 223-232, 1978.

15.S. R. Holden and K. Treseder, "A meta-analysis of soil microbial biomass responses to forest disturbances", Frontiers in Microbiology, vol. 4, 163, 1-17, 2013.

16.D. Holscher, B. Ludwig, R.F. Müller, H. Fölster, "Dynamic of soil chemical parameters in shifting cultivation agriculture in the eastern Amazon", Agric. Ecosys. Environ., vol. 66, 153-63. 1997.

17.O. Huber, "Significance of savanna vegetation in the Amazon Territory of Venezuela". In: G. Prance (Editor), Biological Diversification in the Tropics. Columbia University Press, New York, 221-244. 1982. 
18.C.F. Jordan, Amazonian Rain Forests: Ecosystem Disturbance and Recovery. Ecological Studies 60 SpringerVerlag, New York, 133. 1987.

19.C.F. Jordan, Nutrient cycling in Tropical forest ecosystems: Principles and their application in management and conservation. John Wiley \& Sons, 1985. pp. 187.

20.P. Lavelle, M. Dangerfield, C. Fragoso, V., Eschenbrenner, D. López-Hernández, B. Pashanasi and L. Brussaard, The Biology Management of Tropical Soil Fertility: The relationship between soil macrofauna and tropical soil fertility. O.L. Woomer, \& M.J. Swift. (Eds.), TSBF: A Wiley-Sayce Publication, 1994, 137-169.

21.D. López-Hernández, D. "Impact of agriculture and livestock production on tropical soils in Latin America. In: Global land use change: A perspective from the Columbian Encounter. Chapter 16: 405-418. Editores: B.L. Turner, A. Gómez-Sal, F. González Bernáldez and F. Di Castri. Consejo Supremo de Investigaciones Científicas (CSIC). 1995.

22.D. López-Hernández, "Soils with hardened laterites are they really high P-sorbing?" CIENCIA, vol. 24, 178-186, 2016.

23.D. López-Hernández, "Agricultural systems in the savanna-forest ecotone of Venezuelan Amazonian. Evaluation of soil quality indicators". Chapter 1. In: Amazon Basin: Plant Life, Wildlife and Environment. Environmental Research Advances Series. Nicolas Rojas and Rafael Prieto (eds). NovaScience Publishers Inc. 2010, 1-45.

24.D. López-Hernández and C.P. Burnham, "The covariance of phosphate sorption with other soil properties in some British and tropical soils". J Soil Sci., vol. 25, 196-206, 1974.

25.D. López-Hernández and C. Infante, "N Cycle in a Venezuelan Sugarcane Plantation. How Biogeochemical Processes Contribute to Supply N Needs". ST Agri Science, vol. 1, 1003, 2016.

26.D. López-Hernández, M. P. García-Guadilla, F. Torres, P. Chacón and M.G. Paoletti, "Identification, characterization and preliminar evaluation of Venezuelan Amazonian production systems in Puerto Ayacucho savanna-forest ecotone", Interciencia, 22, 307-314,1997.

27.MARNR, Sistemas Ambientales Venezolanos. Proyecto VEN 79-001. Región Guayana. Territorio Federal Amazonas. 3 vol. Caracas, 1983.

28.D. A. McGrath, C. K. Smith, H. L. Gholz and F. de A. Oliveira, "Effects of Land-Use Change on Soil Nutrient Dynamics in Amazônia" Ecosystems 4: 625-645. 2011.

29.J. R. Miesel, R. E. J. Boerner, and C. N. Skinner, "Soil nitrogen mineralization and enzymatic activities in fire and fire surrogate treatments in California", Can J Soil Sci, vol 91, 935-946, 2001.

30.J. Murphy and J.Riley, "A modified single solution method for the determination of phosphate in natural waters", Anal. Chem. Acta, 27, 31-36. 1962.

31.S. Nazoa and D. López-Hernández, "Contenido nutricional em sabanas de Trachypogon sp., cercanas a Puerto Ayacucho, Venezuela. Acta Biol Venez, vol. 11, 21-50, 1981.

32.R. Pritchard Miller and P.K.R. Nair, "Indigenous agroforestry systems in Amazonia: from prehistory to today", Agroforestry Systems, vol. 66, 151-164, 2006.

33.J. Reed, J. van Vianen, S. Foli, J. Clendenning, K. Yang, M. MacDonald ,G. Petrokofsky, C. Padoch , T. Sunderland, "Trees for life: The ecosystem service contribution of trees to food production and livelihoods in the tropics", Policy and Economics, 2017.

34.A. A. Ribeiro Filho, C. Adams, R. S. Sereni Murrieta, "The impacts of shifting cultivation on tropical forest soil: a review", Bol. Mus. Para. Emílio Goeldi. Cienc. Hum., Belém, vol. 8, 693-727, 2013

35.P. Sánchez and J. Salinas, "Suelos ácidos y estrategias para su manejo con bajos insumos en América Tropical," Sociedad Colombiana de Ciencia del Suelo, Bogotá, Colombia, 1983.

36.G. Stanford and S. J. Smith, "Nitrogen mineralization potentials of soils", Soil Sci. Soc Amer Proc, vol 36, 465$472,1972$.

37.E. Szczerban, Geología y Petrología del Área de Puerto Ayacucho, Territorio Federal Amazonas, Venezuela. Unidad de Geología. MOP. Caracas. CODESUR. 1974.

38.M. A. Tabatabai and J. M. Bremner, "Use de p-nitrophenyl phosphate for assay of soil phosphatase activity", Soil Biol Biochem, vol. 1, 301-307. 1969.

39.M. A. Tabatabai and J. M. Bremner, "Assay of urease activity in soils", Soil Biol Biochem, vol. 4, 479-487, 1972. 40.USDA, Reference to Soil Taxonomy. Washington D. C. USA. 1994.

41.E. D. Vance, P. C. Brookes and D. S. Jenkinson, "An extraction method for measuring soil microbial biomass C", Soil. Biol. Biochem., 19,703-707, 1987. 
42.M.P. Waldrop, T.C. Balser and M.K. Firestone, "Linking microbial community composition to function in a tropical soil", Soil Biol Biochem, vol. 32, 1837-1846, 2000.

43.S. Wunder, "Payments for environmental services and the poor: concepts and preliminary evidence". Environ. Dev. Econ. 13, 279-297, 2008. 